\title{
ISLAMIC MEDICAL ETHICS: The IMANA Perspective
}

\author{
IMANA Ethics Committee
}

Shahid Athar, MD, Chair

Wahaj D. Ahmed, MD
Malika Haque, MD
Hussain F. Nagamia, MD
Hassan Hathout, MD, PhD (advisor)

Hossam E. Fadel, MD, Vice-Chair

\author{
Abdul R.C. Amine, MD \\ Faroque A. Khan, MD \\ Hasan Shanawani, MD
}

\begin{abstract}
Acknowledgment
Iltifat Alavi, MD, Acting Executive Director Mohammed I. Ahmed, MBBS, MS (Surgery)

IMANA HQ Management
\end{abstract}

\section{CONTENTS}

$=========$

1. Introduction of IMANA

2. Islamic Medical Ethics

3. Need for IMANA'S Perspective on Islamic Medical Ethics

4. IMANA's Perspective on Important Ethical Issues

A. The Care of The Muslim Patient

B. Definition of Life and Responsibility of Muslim Physicians Towards Human Life

C. Definition of Death

D. Mechanical Life Support in Terminally III Patients or those in Persistent Vegetative State and Euthanasia

E. Islamic Living Will and Advance Directive

F. Organ Donation and Transplantation

G. Assisted Reproductive Technologies and Surrogacy

H. Contraception and Sterilization

I. Termination of Pregnancy (TOP)

J. Genetic Engineering and Human Cloning

K. Care of HIV Infected/AIDS Patients

L. Examination of Patients of Opposite Sex

M. Drug Research

5. References

\section{APPENDIX}

ニニニニニニニニニニニ

Websites on Islam, Islamic Medicine and Islamic Medical Ethics

\section{INTRODUCTION OF IMANA}

In 1963, Muslim students studying in American colleges and universities organized themselves into an association, the Muslim Students' Association (MSA). Four years later, in 1967, American Muslim physicians did the same and formed the Islamic Medical Association of North America (IMANA). MSA transformed into the Islamic Society of North America (ISNA) and IMANA became a constituent body of ISNA. Since its inception in 1967, IMANA has dedicated itself to serving Muslim physicians, Muslim allied health care professionals, Muslim patients and the community at large on issues related to Islamic Medicine nationally and worldwide. IMANA is also a member of the international Federation of Islamic Medical Associations (FIMA). Islamic Medicine is defined as the art and science of practice of medicine by Muslim physicians and other health care providers in the service of humanity under Islamic guidelines as ordained by the divine book al-Qur'an and taught by Prophet Muhammad, peace be upon him (PBUH). IMANA has headquarters in a Chicago suburb and regional chapters in many cities of USA. It is governed by a Board of Regents and an executive committee according to established by-laws. It has several operational committees including the medical ethics committee. For detailed information about IMANA, one can visit www.imana.org. 


\section{ISLAMIC MEDICAL ETHICS}

\section{ニニニニニニニニニニニニニニニニニニニニニニニニニニニニニニニニニニ}

Islam considers access to health care as a fundamental right of the individual. In medicine, there are sometimes difficult decision-making options for the patient's care. Thus, a physician at times has to decide for his /her patient in light of available knowledge, his/her experience, his/her peers and consensus of the community. In addition, a Muslim physician derives his /her conclusion from rules of Islamic laws (Shari ah) and Islamic medical ethics. The first main principle of Islamic Medicine is the emphasis on the sanctity of human life which derives from alQur'an:

Whosoever saves a human life, saves the life of the whole mankind. ${ }^{1}$

The second main principle is the emphasis on seeking a cure. This derives from a saying of Prophet Muhammad (PBUH):

There is no disease that God has created, except that $\mathrm{He}$ also has created its treatment. $^{2}$

Prophet Muhammad (PBUH), in another narration, is also reported to have said:

Seek treatment, for God the Exalted did not create a disease for which He did not create a treatment, except senility. ${ }^{3}$

This is further emphasized by the fact that three of the "Goals of the Islamic Shari ah" are the protection and preservation of life, intellect, and progeny. The other two are the protection of property and religion.

Some of the rules of Islamic medical ethics are 1) Necessity overrides prohibition; that is, if there are certain items which are Islamically prohibited, under dire necessity they can become permissible. 2) Harm has to be removed at every cost if possible. 3) Accept the lesser of the two harms if both can not be avoided. 4) Public interest overrides the individual interest.
Islamic Medical Ethics also upholds the four basic principles of biomedical ethics. These are 1) Respect for the autonomy of the patient, 2) Beneficence, 3) Nonmaleficence, and 4) Distributive Justice.

Thus, when a Muslim physician is making a decision about patient care, that decision should be in the best interest of the patient, whether Muslim or non-Muslim. Further, that decision should not only be based on his/her own knowledge and experience, but as a Muslim, he/she has to consider the Islamic teaching in regards to the situation, but without imposing his/her religious views on the patient.

\section{NEED FOR IMANA'S PERSPECTIVE ON ISLAMIC MEDICAL ETHICS}

ニニニニニニニニニニニニニニニニニニニニニニニニニニニニニニニニニニ
Muslim Physicians, Ethicists, Imams and scholars are asked questions by Muslim and nonMuslim patients, physicians and institutions as to what is Islam's position or opinion on certain medical dilemmas affecting the care and outcome of patients' illness and life. Some of these issues, such as termination of pregnancy, are time honored situations while many such as transplantation, assisted reproduction and life support are products of advances in medical technology. Since these are new issues, Muslim physicians, have dire need for recommendations from the guiding principles of the Glorious Qur'an, the tradition of Prophet Muhammad (PBUH) and opinions of past and contemporary Muslim scholars. The Qur'an says:

It is not fitting for a believer, man or woman, when a matter has been decided by God, and His messenger, to have any option about their decision. If any one disobeys God and His messenger, he is indeed on a clearly wrong path. 4

Thus, IMANA decided to make a position paper, "The IMANA Perspective", to provide to those who seek our opinion and enable them to pursue further reading on their own. The positions expressed in this perspective are only suggestions on behalf of IMANA and are not to be considered Fatwa(s) (religious decrees) which are

JIMA: Volume 37, 2005 - Page 34 
religiously binding. The members of ethics committee are not in a position to issue a Fatwa on any of the issues which we are writing on behalf of IMANA. However, from time to time, on a need basis, we do consult Muslim scholars to have their opinion. These positions will be revised from time to time as new questions arise from advances in medical technology. The position paper is available to be read and downloaded from internet at www.imana.org at no cost.

\section{IMANA'S PERSPECTIVE ON IMPORTANT ETHICAL ISSUES}

(A) Care of the Muslim Patient

IMANA has published a brochure entitled "Guidelines for Healthcare Providers in Caring for Muslim Patients". 5,6 Those who wish to obtain a copy can call IMANA at (630) 932-0000. It is also available on line at www.imana.org, in the Health and Ethics section.

All patients irrespective of their faith should be treated with human dignity and respect. Muslim physicians are advised to treat all patients with loving care as if they are members of their own family. We suggest to all health care providers that they familiarize themselves with the basic teachings of Islam and Islamic moral values. It is easier for a healthcare provider to deal with the patient if he/she understands the faith, values and culture of his/her patient. These are some of the specific guidelines for healthcare providers especially of other faith traditions for caring for their Muslim patients.

1. Muslim patients should be identified-if possible-as Muslim (or with the religion Islam) in the registration information so as to prevent any mistakes happening unintentionally in terms of violating dietary rules or privacy.

2. Their care providers should respect their modesty and privacy. Muslim patients, particularly women, may need a special gown to cover the whole body in order to avoid unnecessary exposure during physical examination. Some examinations may be done over the gown.

3. Provide Muslim patients Islamically slaugh- tered (Dhabiha) meat. Muslim patients should not be served any pork, pork products or alcohol in their meals. A Muslim patient's family may be allowed to bring food from home, as long as it is meeting the patient's dietary restrictions.

4. Make it easy for Muslim patients to perform Islamic prayers if they can.

5. Inform them of their rights as a patient and encourage an Islamic living will. A sample of a living will is included. (see Section E)

6. Take time to explain test procedures and treatment. Some of the more recently immigrated Muslims may have a language problem. Muslim women can give consent for any treatment or procedure.

7. Allow their Imam (religious teacher) to visit them and pray for them. Clerics of other faith traditions can pray for or with Muslim patients with their permission, using non denominational words like God.

8. Autopsy is permitted if medically indicated or required by law.

9. Organ donation is permitted with some guidelines and is encouraged.

10. Always examine a female patient in the presence of another female (chaperon) or a female relative (except in medical emergencies). Especially for labor and delivery, if the patient's obstetrician is unavailable and upon her request, provide a female healthcare provider, if feasible. Her husband is encouraged to be present during the delivery.

11. After the death of a Muslim patient in a health care facility, allow the family and Imam to arrange for preparing the dead body for burial under Islamic guidelines. A corpse should be given the same respect and privacy as he/she was receiving while alive. Muslim relatives and friends of the dead are encouraged to stay in the room where the dead body is kept to recite Qur'an. Muslim corpses are not embalmed.

(B) Definition of Life and the Responsibility of Muslim Physicians towards Human Life Muslims believe that God is the Creator of life and life is a gift from Him. Muslims believe that all life is sacred and must be protected. The 
respect for life in Islam is common for all humans, irrespective of gender, age, race, color, faith, ethnic origin or financial status.

IMANA holds the position that biological life begins at conception while human life begins when ensoulment takes place. A verse from the Qur'an reads:

Man We did create from a quintessence (of clay); Then We placed him as (a drop of) sperm in a place of rest, firmly fixed; Then We made the sperm into a clot of congealed blood; then of that clot We made a (fetus) lump; then we made out of that lump bones and clothed the bones with flesh; then we developed out of it another creature. So blessed be God, the best to create! ${ }^{7}$

Ensoulment is believed to occur at 40 or 120 days after fertilization, according to different schools of thought. ${ }^{8}$ (see Section I) The right of the human fetus in Islam is similar to the rights of a mature human being, including the right to life, the right to inheritance, the right of compensation when injured by willful acts and the right to penalize assailants.

IMANA extends the principles of medical ethics to the patient in a vegetative state. Until the death has been declared, the patient in a vegetative state is considered a living person and has all the rights of a living person.

\section{(C) Definition of Death}

The definition of the end of human life from the Islamic point of view has been previously discussed. 9,10 IMANA has previously published a position paper on death. ${ }^{11}$ Permanent cessation of cardiopulmonary function, when diagnosed by a physician or a team of physicians, is considered death. The concept of brain death is necessitated when artificial means to maintain cardiopulmonary function are employed. In those situations, cortical and brain stem death, as established by specialist(s) using appropriate investigations can be used. It is the attending physician who should be responsible for making the diagnosis of death. Thus a person is consid- ered dead when the conditions given below are met.

1. The physician has determined that after a standard examination, a person's cardiopulmonary function has come to a permanent stop.

2. A specialist physician (or physicians) has determined that after standard examination, the function of the brain, including the brain stem, has come to a permanent stop, even if some other organs may continue to show spontaneous activity.

\section{(D) Mechanical Life Support in Terminally III Patients or Those in Persistent Vegetative State and Euthanasia}

The following verses in the Glorious Qur'an are some of the verses which address issues of life and death.

It is He who gives life and death and when He decides upon an affair, He says to it: Be and it is. ${ }^{12}$

No soul can die except by God's permission, the term being fixed by writing... ${ }^{13}$

Every soul will have a taste of death. In the end, to us, shall you be brought back. ${ }^{14}$

It is He who gives life and Who takes it away and to Him shall you be brought back. ${ }^{15}$

Nor take life which God has made sacredexcept for a just cause... ${ }^{16}$

IMANA does not believe in prolonging the misery of dying patients who are terminally ill or in a persistent vegetative state (PVS). PVS is defined as a sub-acute or chronic condition which usually follows severe brain injury and is characterized by normal sleep/wake pattern and total lack of cognitive function with preserved blood pressure, respiratory control, that persists for more than two months.

When death becomes inevitable, as determined 
by a team of physicians, including critical care physicians, the patient should be allowed to die without unnecessary procedures. While all ongoing medical treatments can be continued, no further or new attempts should be made to sustain artificial life support. If the patient is on mechanical support, this can be withdrawn. ${ }^{17-20}$

The patient should be treated with full respect, comfort measures and pain control. No attempt should be made to withhold nutrition and hydration. In such cases, if and when the feeding tube has been withdrawn, it may not be reinserted. The patient should be allowed to die peacefully and comfortably. However, no attempt should be made to enhance the dying process in patients on life support.

IMANA is absolutely opposed to euthanasia and assisted suicide in terminally ill patients by healthcare providers or by patient's relatives. Suicide and euthanasia are prohibited in Islam. ${ }^{18,21}$

(E) Islamic Living Will and Advance Directive IMANA recommends that all Muslims have a "Living Will", "Advance Directive" and a case manger for their care, to help physicians to know their wishes, when he or she is unable to give directions (i.e. in a coma). ${ }^{20} \mathrm{~A}$ sample of such proposed living will is provided here which can be modified by the patient after consulting with family and /or an attorney.

\section{(Sample)}

Declaration made this day of 20_, , a Muslim of sound mind, willfully and voluntarily make known my desires that my dying shall not be artificially prolonged under the circumstances set forth below and I declare: If at any time I have an incurable injury, disease or illness certified in writing to be a terminal condition by my attending physician(s), and my attending physician has determined that the use of life-prolonging procedures would serve only to artificially prolong the dying process, I direct that such procedures be withheld or withdrawn, and that I be permitted to die naturally with only the provision of appropriate nutrition and hydration and the administration of essential medications and the performances of any medical procedures necessary (as determined by my physician) to provide me with comfort or to alleviate pain.

In the absence of my ability to give direction regarding the use of life-prolonging procedures, it is my intention that this declaration be honored by my family and physician as the final expression of my legal right to refuse medical or surgical treatment and I accept the consequences of the refusal.

is my case manager to enforce my living will, if I am not physically able to give direction. I do not permit autopsy of my body unless my death occurred in a suspicious manner and it is important to know the cause of death or if it is required by the court of law. It is my desire that Muslims attending my dying process ensure that Islamic Shari'ah is practiced during preparation of my body for burial and that my body be treated with grace and privacy and buried with Islamic guidelines under the directions of my Muslim family, Imam or other qualified Muslims as soon as it is feasible.

Signed Date

Place

The declaring person has been personally known to me and I believe (him/her) to be of sound mind. I did not sign the declaring person's signature above for or at the direction of the declaring person. I am not a parent, spouse, or child of the declaring person. I am not entitled to any part of the declaring person's estate or directly financially responsible for his/her medical care. I am competent and at least eighteen (18) years of age.

Witness (to the document)

Date

Witness (second)

Date 
(F) Organ Donation and Transplantation We, at IMANA, understand that certain organs may fail in the human body while the rest of the body may still be functional. The current state of medical knowledge holds the view with scientific proof that, if the diseased organs are replaced by healthy organs and if accepted, the body machine can continue to function rather than die because of one diseased organ. Islam instructs all Muslims to save life. ${ }^{1}$ Thus, on this basis, transplantation in general, both giving and receiving organs, is allowed for the purpose of saving life. ${ }^{22-25}$ This has to be done under the following guidelines:

1. The medical need has to be defined.

2. The possible benefit to the patient has to be defined.

3. Consent from the donor as well as the recipient must be obtained.

4. There should be no sale of organs by any party.

5. No financial incentive to the donor or his relatives for giving his organs, but a voluntary gift may be permitted. On the other hand, there should be no cost to the family of the donor for removing the organ.

6. Any permanent harm to the donor must be avoided.

7. Transplantion of sex organs (testicles or ovaries) which would violate the sanctity of marriage is forbidden.

8. Cadaver donation is permitted but only if specifically mentioned in that person's will or in driving license.

Blood Transfusion is permissible. Giving blood to or receiving blood from people of other faiths is permissible.

\section{(G) Assisted Reproductive Technologies and Surrogacy}

We believe infertility is a disease and desire for a cure by an infertile couple is natural. However, in Islam, for an action to be permissible all means of achieving that action are also to be pure.

We believe in the sanctity of marriage and the importance of preserving lineage.
The Qur'an says:

And God has made for you mates (and companions) of your own nature, and made for you, out of them, sons and daughters and grandchildren, and provided for you sustenance of the best: will they then believe in vain things, and be ungrateful for God's favours?26

\section{The Qur'an says:}

It is He who has created man from water: then has He established relationships of lineage and marriage: for thy Lord has power (over all things). ${ }^{27}$

Based on these Qur'anic guidelines, IMANA holds the following positions:

1. All forms of assisted reproductive technologies (ART) are permissible between husband and wife during the span of their marriage using the husband's sperm and the wife's ovaries and uterus. No third party involvement is allowed.22,28,29 We believe in the sanctity of marriage and that the death of the husband terminates the marriage contract on earth, thus frozen sperm from a deceased husband can not be used to impregnate his widow.

2. Sperm, ova and embryo donation are not permitted.

3. Additional embryos produced by IVF between husband and wife can be discarded or given for genetic research, if not to be used by the same couple for a future attempt. 22

4. Surrogacy involving a third person is not permissible, as we believe that it exceeds the boundaries of the marriage contract and lineage. ${ }^{27-32}$

5. Use of fertility drugs is permissible.

An infertile couple, if they can not find a permissible cure, can care for an orphan or someone else's child as their own within the Islamic guidelines of adoption, not the legal adoption as practiced in the United States. 


\section{(H) Contraception and Sterilization}

Islam prohibits sex out of wedlock.

\section{(i) Contraception}

For married couples, contraception for several reasons, including health of the mother, social or economic reasons etc, is permitted, provided that it is practiced by mutual agreement of the husband and wife and that the method used is reversible and not harmful. Withdrawal, prophylactics, birth control pills and other hormonal methods are allowed. Contraceptive methods which can lead to abortion are not allowed.22,31

\section{(ii) Sterilization}

Sterilization, whether by vasectomy or tubal ligation, as a national policy for family planning or population control, is unlawful and should not be allowed. 22

On an individual level it is permissible provided that both husband and wife want it and:

1. When there is a significant medical contraindication to the pregnancy, for example, if there is a significant risk to the wife's health if she conceives.

2. When other methods of birth control have failed or are causing significant side effects.

3. When a genetic disease of the husband or wife or both poses a high risk of being transmitted to the fetus e.g. autosomal dominant or autosaul recessive conditions when both husband and wife are carriers.

4. When it is done for family planning, i.e., the husband and wife are satisfied with the number of children they have, some scholars will permit it but it is makrouh (hated). ${ }^{22}$

\section{(I) Termination of Pregnancy (TOP)}

Abortion is the willful termination of pregnancy by artificial means: drugs, chemicals, mechanical or surgical procedures before the age of viability (23 menstrual weeks, i.e. calculated from the first day of the last menstrual period) for any reason. Chemical or mechanical means to prevent the formation of zygote (fertilized ovum, which marks the beginning of human life) is not considered abortion. We believe that life begins at con- ception and unless interrupted by disease or artificial means, the fertilized ovum will continue to grow and become a viable mature human being. However, some scholars differentiate between biological life, which starts at conception, and human life, which starts after ensoulment. 7,8 The two Shaykhs (al-Bukhari and Muslim) relate on the authority of 'Abdullah ibn Mas'ud that God's Messenger (PBUH), has said:

The creation of each one of you is brought in the belly of his mother for forty days, then for a similar period he is a germ cell, then for another forty days he is an embryonic lump, then an angel is sent to him and ordered to write down four words. He is told: "write down his career, his livelihood, his life duration and whether he is to be miserable or happy, and the angel breathes spirit into $\operatorname{him} . .33,34$

Further, the time of ensoulment according to this hadith is considered to be at $\mathbf{4 0}$ days after fertilization by some scholars, while others consider it to be at 120 days after fertilization. 8

IMANA's position on abortion22,25,32,35,36 can be classified as follows:

1. Elective abortion of a viable fetus in a healthy mother is prohibited.

2. Abortion is permitted if continuation of pregnancy may cause the pregnant woman to die or cause serious deterioration of her health, both medical and mental, if done before 120 days after fertilization, i.e. 19 menstrual weeks.

3. Fetal congenital malformations in which abortion can be sought and is permitted are lethal malformations not compatible with extra uterine life such as bilateral renal aplasia, Trisomy 13, 18, etc. But even in these situations it is preferable to do it before the 120th day after fertilization or 19 weeks of gestation, calculated from the first day of the last menstrual period.

4. In non-lethal malformations such as severe hydrocephaly, cervical meningomyelocele, Down's syndrome and unbalanced translo- 
cations, abortion may be permissible before the 120th day of conception after consulting Islamic scholars and medical experts in the field.

5. Pregnancy occurring because of rape, war crimes and incest may be a cause to seek abortion.

In all cases in which abortion is sought, the recommendation should be made by a team of Islamic scholars and medical experts in the field.

Prohibition of infanticide is mentioned in several Qur'anic verses. One of these verses is:

Kill not your children for fear of want: We shall provide sustenance for them as well as for you. Verily the killing of them is a great $\sin .37$

(J) Genetic Engineering and Human Cloning Genetic research and engineering to alter or delete diseased genes is allowed and genetic research using stem cells from products of miscarriages or surplus ova after IVF procedures is permissible. However, to conceive in order to abort the fetus and harvest and use its stem cells is not permissible. ${ }^{38-42}$

We believe that each individual is born with unique qualities and genetic makeup. Islamically, a child should be born out of marriage between husband and wife and the lineage of the child should be maintained. 27 Therefore, human reproductive cloning is not permitted in Islam. 43,44

Therapeutic cloning may be permissible within strict guidelines. 43

\section{(K) Care of the HIV Infected/AIDS Patient} HIV infection, in addition to being associated with homosexuality, is also known to be acquired through heterosexual acts, as well as intravenous drug use, blood transfusion and child birth. While Islam is opposed to homosexual lifestyle, promiscuity, and drug abuse, IMANA is not opposed to the care of HIV patients. In fact, it instructs Muslim physicians to care for HIV patients with the same degree of compassion as they would for other patients. 45

We do not discriminate against any patient on the basis of their lifestyle. We do advise healthcare providers to take precautions for themselves while taking care of HIV patients.

\section{(L) Examination of Patients of the Opposite Sex}

IMANA encourages but does not mandate same sex health care provider. Examination of a patient of the opposite sex is allowed in the presence of a third person of the same sex as that of the patient. In case of a minor, one of the parents' presences is desirable. Only necessary examination needs to be done. Pelvic examination must be done using gloves. Medical or nursing students may be allowed during examination of a female patient, but only with her prior consent and in the presence of a female nurse or relative. 46

\section{(M) Drug Research}

Biomedical research involving double blind trials, controls and the use of placebos in drug research is allowed, but the patient must be informed and consent must be taken. Worsening of the disease while in drug research, either due to placebo or an ineffective dosage of the drug, must be carefully monitored and the trial should be ended for the safety of the patient. 47

\section{Appendix: Websites on Islam, Islamic Medicine and Islamic Medical Ethics}

$\begin{array}{ll}\text { 1. } & \text { www.islamicmedicine.org } \\ \text { 2. } & \text { www.islamonline.net } \\ \text { 3. } & \text { www.islamfortoday.com } \\ \text { 4. } & \text { www.islam-usa.com } \\ \text { 5. } & \text { www.imana.org } \\ \text { 6. } & \text { www.iiim.org } \\ \text { 7. } & \text { www.islamicity.org } \\ \text { 8. } & \text { www.ima.org.za } \\ \text { 9. } & \text { www.fimaweb.org } \\ \text { 10. } & \text { www.islamset.com }\end{array}$

\section{References}

1. The Glorious Qur'an, Chapter 5, Verse 32.

2. Sahih Al-Bukhari, Book 79, Kitaab al-Tibb,

JIMA: Volume 37, 2005 - Page 40 
Chapter 1, Hadith 5354. [on-line] Available from: http://www.muhaddith.org.

3. Sunan Abi Dawuud. Vol. 2, Book 27, Kitaab al-Tibb, Chapter 1, Hadith 3855. [on-line] Available from: http://www.muhaddith.org. 4. The Glorious Qur'an, Chapter 33, Verse 36. 5. Medical Ethics Committee, Islamic Medical Association of North America. The Guidelines for Health Care Providers When Dealing with Muslim Patients. J Islam Med Assn 1998;30:4445.

6. Pennachio DL. Cultural Competence: Caring for your Muslim Patients. Medical Economics May 6, 2005, p. 47.

7. The Glorious Qur'an Chapter 23, Verses 1214.

8. Yaseen MN. The Inception of Human Life in the Light of Statements of The Holy Qur'an and Sunnah and the Opinions of Muslim Scholars. J Islam Med Assn 1990;22:159-67.

9. Yaseen MN. The End of Human Life in Light of The Opinion of Muslim Scholars and Medical Science. J Islam Med Assn 1991;23:74-81. 10. Ahmed WD. An Islamic View of Death and Dying. J Islam Med Assn 1996;28:175-7. 11. Medical Ethics Committee, Islamic Medical Association of North America. Death. J Islam Med. Assn 1997;29:99.

12. The Glorious Qur'an Chapter 40, Verse 68. 13. The Glorious Qur'an Chapter 3, Verse 145. 14. The Glorious Qur'an Chapter 29, Verse 57. 15. The Glorious Qur'an Chapter 10, Verse 56. 16. The Glorious Qur'an Chapter 17, Verse 33. 17. Ebrahim AM. ICU Ethical Dilemmas. The Islamic Medical Association of South Africa2004

18. Medical Ethics Committee, Islamic Medical Association of North America. Care at the End of Life and Euthanasia. J Islam Med Assn 1997; 29:100-101.

19. Athar S. Ethical Decision Making in Patient Care. In Health Concerns for Believers: Contemporary Issues. Chicago: Kazi Publications; January 1996, pp 79-84. 20. Khan FA. Religious Teachings and Reflections in Advance Directive-Religious Values and Legal Dilemmas in Bioethics: An Islamic Perspective. Fordham Urban Law Journal. 2002;30(1):267-75.

21. Hathout $\mathrm{H}$. Islam and Euthanasia.(Guest
Editorial) J Islam Med Assn 1994;26:152-4. 22. Al-Abd OM. Islamic Organization for Medical Sciences. Islamic Law Ruling on Certain Medical Questions-The Argument and Supporting Evidence, 2004. [on-line] Available from: http://www.islamset.com/ioms/Code2004/Islamic _vision2.html.

23. Ebrahim AM. Organ Transplantation: An Islamic Ethico-Legal Perspective. In: Fadel HE, editor, FIMA Yearbook. Islamabad, Pakistan: Federation of Islamic Medical Associations and Medico Islamic Research Council; 2002. pp. 6986.

24. Mehic B. Organ Transplantation in the Light of the Shari'ah: A Jurist Medical Opinion from Bosnia. In: Fadel HE, editor, FIMA Yearbook. Islamabad, Pakistan: Federation of Islamic Medical Associations and Medico Islamic Research Council; 2002. pp. 87-96. 25. Athar S. Islamic Perspectives in Medical Ethics. In: Athar S, editor. Islamic Perspectives in Medicine: A Survey of Islamic Medicine:

Achievements \& Contemporary Issues. Chicago: Kazi Publications; 1996. pp. 187-94.

26. The Glorious Qur'an Chapter 16, Verse 72. 27. The Glorious Qur'an Chapter 25, Verse 54. 28. Fadel HE The Islamic Viewpoint on New Assisted Reproductive Technologies. Fordham Urban Law Journal. 2002;30(1):147-57.

29. Fadel HE. Assisted Reproductive Technologies. An Islamic Perspective. In: Fadel HE, editor, FIMA Yearbook. Islamabad, Pakistan: Federation of Islamic Medical Associations and Medico Islamic Research Council; 2002. pp. 5968.

30. Hathout, M: Surrogacy, An Islamic

Perspective; J Islam Med Assn 1989,21:157-60

31. The Glorious Qur'an Chapter 58, Verse 2.

"... None can be their mothers except those who gave them birth..."

32. Ebrahim AM. Abortion, Birth Control \& Surrogate Parenting: An Islamic Perspective. Indianapolis, USA: American Trust Publications; 1990.

33. Ibn Hajar al-'Asqalani. Fath al-Bari bi-Sharh Sahih al-Bukhari (The Creator's Inspiration in Interpreting the Verified Collection of al-Bukhari). Cairo, Egypt: Al-Bahiyyah Egyptian Press; 1930. Vol 11, p. 405.

34. Sahih Muslim bi Sharh al-Nawawi (Muslim's 
Verified Collection with al-Nawawi's Interpretation). 1st Ed. Cairo, Egypt: Al-Azhar Egyptian Press, 1930. Vol. 16, p. 190.

35. Fadel HE. Antenatal Diagnosis of Fetal Malformations: Achievements, Pitfalls, and Dilemmas. J Islam Med Assn 1998;30:99-101. 36. Albar MA. Induced Abortion: Is it Still Criminal or Just Elective? With Emphasis on Islamic Perspective. In: Fadel HE, editor, FIMA Yearbook. Islamabad, Pakistan: Federation of Islamic Medical Associations and Medico Islamic Research Council; 2002. pp. 15-32.

37. The Glorious Qur'an Chapter 17, Verse 31. 38. Siddiqi M, Siddiqi I. An Islamic Perspective on Stem Cell Research. Pakistan Link 2001. 39. El-Hazmi AF. Ethics of genetic counseling. Annals of Saudi Medicine 2004;24(2):84-92. 40. Ahmed WD. Ethics Committee Commentary on Gene Therapy. J Islam Med Assn 1993;25:8. 41. Ahmed AJ. Gene Therapy-Promises and Issues. J Islam Med Assn 1993;25:25-9. 42. Albar MA. Ethical Considerations in the Prevention and Management of Genetic Disorders with Special Emphasis on Religious Considerations. In: Fadel HE, editor, FIMA Yearbook. Islamabad, Pakistan: Federation of Islamic Medical Associations and Medico Islamic Research Council; 2002. pp. 49-58.
43. Fadel HE. Cloning: The Role of Muslim Scientists and Scholars. Editorial. J Islam Med Assn 1997;29:51-3.

44. Mishal AA. Cloning and Advances in Molecular Biotechnology: Islamic Shari'ah Guidelines. In: Fadel HE, editor, FIMA Yearbook. Islamabad, Pakistan: Federation of Islamic Medical Associations and Medico Islamic Research Council; 2002. pp. 33-48.

45. Gray PB. HIV and Islam. Social Science and Medicine 2004;58:1751-6.

46. Athar S. Contemporary Issues in the Practice of Islamic Medicine. J Islam Med Assn 1996;28:195-7.

47. International Ethical Guidelines for Biomedical Research Involving Human Subjects (An Islamic Perspective) - Prepared by The Council for International Organizations of Medical Sciences (CIOMS) in cooperation with $\mathrm{WHO}$ and the Islamic Organization for Medical Sciences, IOMS, Geneva, The Islamic Organization for Medical Sciences. In press 2004.

Unless otherwise noted, all quotations of The Glorious Qur'an are from the Abdullah Yusuf Ali Translation, Amana Publications. 